\title{
Assessment the Water Supply System of Qom City Based on the Water Safety Plan
}

\author{
$\underline{\text { Sanaz Nozariamini }}{ }^{1}$, Sara Miryousefi Ata ${ }^{2}$, Bakhrul Khair Amal ${ }^{3}$ \\ ${ }^{1}$ Transportation Engineer Dot California, Alumni California polytechnic University Pomona, United \\ State \\ ${ }^{2} \mathrm{PhD}$ Candidate at Louisiana State University, United State \\ ${ }^{3}$ Anthropological Education Department, Faculty of Social Science, Universitas Negeri Medan, \\ Indoneia \\ Email: sanaz.nozariamini@gmail.com; b4khrul.4m41@gmail.com
}

\begin{abstract}
:
The existing condition of potable water in the city of Qom and its adjacent villages needs improvement, both for the quantity as well as the quality. On one side, the excess use of wells has decreased the level of underground water, resulting to Penetration of salty water from the neighboring salt lake into the underground water and therefore, lowering the quality of potable water, and on the other side, during the recent years the consumption of water has increased due to grow th of the city population. Because of these factors, the improvement of quality and overcoming the shortage of drinkable water in the city of Qom and its adjacent villages, have turned to an urgent need. To respond to the above-mentioned needs, some studies have been carried out by a number of consultants during the past years. In addition, based on such studies, certain projects have been implemented to provide new sources of potable water for the city of Qom.this paper aims at investigating the existing condition of potable water in the city of Qom. The goal of this water treatment is to supply the drinkable water for agriculture and industry and producing the energy.
\end{abstract}

Keywords:

water safety plan; water distribution network; risk management; drinking water

\section{Introduction}

Qom is a religious city adjacent to the Central desert of Iran with a population of 1,202,000 people (based on 2016 census). It welcomes about 20 million tourists per year from different parts of the country. One of the projects previously implemented to fulfill this shortcoming is the transfer of water from 15 Khordad Dam and the treatment of that water. With the implementation of that project the transmission line from 15 Khordad Dam and the Water Treatment Plant (WTP) of Qom have become operational respectively on 1370 (1991) and 1376 (1997). Under the normal conditions, the treatment capacity of Qom WTP is 55 million cubic meters per year. This amount, by the time that the transmission line from 15 Khordad Dam became operational, used to provide $66 \%$ of the needed drinking water for the city of Qom. (Yekta TS 53-58)

The rest was provided through underground water of wells located in different parts of the city. However, due to increase of the city population, which based on the available statistics has increased 3.5 times during 30 years from 1357 to 1387 (1978 to 2008), and also due to lowering of the underground water. As a result of excess consumption of water. The water resources from the Qom River together with the available surface water currently provide less than $50 \%$ of the required volume of potable water for Qom and its adjacent villages. Considering that in line with the purpose of increasing the volume of potable water for a number of cities, the volume of allocated water from the Dez Head-Branches for the 
cities in Central and Isfahan provinces was increased from 120 to 181 million m3 per year, the studies regarding the transmission of water form Koucheri Dam which was done in the last month of 1387 (February 2008) had to be reviewed. Based on such reviews the execution activities of the aforementioned transmission live were commenced on March 2009. Further studies were required to determine a feasible project to increase the volume of potable water for Qom. Meanwhile, to secure part of finances for the project, negotiations were carried out between Qom Regional Water Authority (QRWA) and Islamic Development Bank (IDB), which resulted to signing of an Agreement between the two parties on May 2009. (World Health Organization 33) Melaku Adinew (2019) in his article entitled Effect of Climate Change on Agricultural Output Growth in Ethiopia: Co-Integration and Vector Error Correction Model Analysis states:

The evidence of the global climate changing and projections showed that the rate of change will increase in the future. Global temperatures are expected to increase by $1.1-2.6^{\circ} \mathrm{C}$ by the end of the 21 ts century. The policymakers and government should implement policies that to promote the use of environmental-friendly machines and technologies that generate smallest greenhouse gases, such as people are encouraging to adopt agro-forestry, use of improved bio-fuels, energy saving machines, climate smart agricultural technologies, like mitigation role such as greenhouse gas emission minimization and adaptation role such as improvement of soil water storage capacity and minimizing soil erosion, farmers will be adopt increasing productivity inputs with in fixed cultivated land rather than expansion of new forest cultivated land.(139-141).

It is foreseen that with the transfer of water from Dez Water Head-Branches through implementation of $180 \mathrm{~km}$ of transmission line from Kouchery Dam to Qom and also with the increase of treatment capacity of Qom WTP from the existing capacity of 55 million cubic meter per year to an additional capacity of 142.5 million cubic meter per year (a total treatment capacity of 197.5 million cubic meter per year), the quality of potable water of Qom would improve and the shortcoming in regard to the required quantity of drinkable water would be overcome.

\section{Review of Literature}

Ministry of Energy and the Water Research Institute of the West Azerbaijan Water Authority (2005) mentioned local and national level that has covered different aspects of Lake Urmia basin, including social economic and environmental to some extent. Chowdhury and Al-Zahrani 2014; Strobl and Robillard (2008) stated that in recent years, the lack of fresh water resources has aroused serious concerns all over the world. Protecting these resources from pollution will reduce water treatment costs. Razmkhah et al. 2010; Tajziehchi (2014a) reported that in Iran, dams serve as the seasonal largest sources of drinking water after underground water, while they are subjected to the risk of quality degradation due to reduced atmospheric precipitation, Disproportionate land uses, excessive operations, and loss of cultural and social identity. Darko et al.2017; (Karamouz et al. 2001; Saadatpour et al. 2017) reported that factors, such as traditional irrigation, energy production, developments of industries requiring plentiful water, intermediate water transfers, and inefficient management of water consumption, have led to the reductions of the quality and quantity of water resources .Kazi et al., (2009) assessed water quality of polluted lake using multivariate statistical techniques.

Zahra Ahmadlia, Mohammad Fahiminiab (2016) in their article entitled Performance Evaluation of Qom Water Treatment of Plant during 2005 to 2014,Iran mentioned the performance of Qom water treatment to remove turbidity and coliforms from 
water in the course of ten years corresponded with the National Iran standard. The mean values of recorded parameters show that the treatment system is functioning well. Because of climate desert of Qom and also probable creating flood conditions in some seasons, creating fluctuations in incoming water to the plant and a sudden increasing in turbidity is possible that shows the importance of preparedness of treatment processes to deal with such critical situations.

\section{Methodology}

This present qualitative study. The drinking water of Qom is supplied from the $15 \mathrm{Khordad}$ dam, Koucheri dam, water wells of Aliabad region, and the water wells inside the city. The water transmitted from 15 Khordad and Koucheri dams enter the water treatment plant with a flow of 2 cubic meters per second. The goal of this dam is supplying the drinkable water, water for agriculture and producing the energy. In this way, exploitation of dams, protection of superficial and underground water sources, preparation and carrying out the national constructive and provincial projects, management of water sources and short time, middle time and longtime programming for studies and supplying the water, are the most important duties of this study. The reason of creation of permanent water treatment plant is transferring the 40 million $\mathrm{m}$ filtered water to Qom city. This water treatment is located in $70 \mathrm{~km}$ far from south of Qom and the source of supplying the water is 15 khordad dam. In filtration level, the water after changing to limpid from by chlorination, becomes disinfected and healthy and transferred to Qom city.

\section{Discussion}

\subsection{Environmental, Public Health, Economic \& Social Effect of Water Treatment}

Although a study has been done on environmental impact of the project, further thorough studies could provide elaborated environmental, public health, economic \& social benefits of the project. However, considering that improvement of quality of drinkable water has been an old wish of the Qom people and also taking into view the pressing demand for increasing the volume of the potable water for growing population in the city Qom, with implementation of this project, a great improvement in quality of water in Qom city and surrounding villages would occur. It would be no exaggeration to say that implementation of the project would be a practical measure to realize such desire and demand.

In short, the rate of access to drinkable water is one of the important criteria to indicate the level of development in any society and Qom with its shortcoming in that regard is not an exception. In addition and more specifically, the implementation of the project would result to the following:

1. The bases of infrastructure as well as the standards of living in the city of Qom and its neighboring villages would be greatly improved.

2. Job opportunities and conditions for expanding businesses would be created and that in turn would positively affect employment rates and economic development.

3. Conditions to prevent massive and uncontrolled immigration of people from villages to bigger cities would be created.

4. There will be highly positive impacts on the Qomrood River status and it is envisaged that the river bed would return back to its original quality conditions.

5. Disease related to poor quality of drinking water would be eliminated and as its result, conditions of public health would be greatly improved. With Implementation of the Qom Water Supply Project (consisting of construction of new Water Treatment Plant, Reservoirs in Doe- Baradaran and Yazdan, Main Distribution pipeline system in North and 
South of the city, and pipeline system from Kouchery Dam to Qom city) in 2012, the amount of 52.6 million cubic meter of water with average Quality of $1000 \mathrm{EC}$ is transferred to the city of Qom. This water is being transferred from Dez water Head-Branches and distributed to some sections of the Qom city and suburbia. The quality of previously used water was about 6000 EC. But later with transferring and distributing the new source of water after mixing with some percentage of the previously used water is about $3000 \mathrm{EC}$. Some of the effects resulting from the improvement in water quality is summarized below:

- Improvement in health conditions and development of infrastructures

- Decreasing in usage of wells in about 53\%

- Highly positive impact on the Qomrood River status as a result of water distribution to villages.

- With continuation of operation of transmission pipeline from Kouchery to the city of Qom, the potable water for the city of Qom is now being provided (with and average of 3 cubic meters per second) with a good quality of EC $<500$ to Water \& Wastewater Company of Qom for distribution in the city.

\subsection{Aims of the Study}

The purpose of this study is to investigate Water Safety Plan in Qom. Considering that the implementation of Qom Water Supply Project and Qom Wastewater Project will be carried out simultaneously, the major development objective of the proposed water projects is:

1. To increase the quantity and improve the quality of drinkable water

2. To improve the environmental conditions

3. Both objectives to be achieved in city of Qom and its neighboring villages. These objectives would be achieved through enhancing the quality of life in the proposed area, particularly in poor areas by:

a) Improving access to satisfactory water supply and significantly increasing coverage of sanitation services;

b) Improving environmental, hygiene and health conditions as well as promoting reuse of treated effluents.

\subsection{Environmental Impact Assessment}

In order to overcome the shortage of drinkable water in some areas, conveying water from one district to another is performed. Even though this method satisfies the need for water in one area, but at the same time it would have unavoidable environmental and social impacts. In this section, we will use the data obtained experimentally and theoretically to study the activities and to evaluate the positive and negative impacts of Qom Water Supply Project in different aspects such as physical, biological, economic, social, etc.

Koto-te-Nyiwa Ngbolua (2019) in his article entitled "Effect of Agricultural Residues Based-Compost on the Yield of Amarantus hybridus L. (Amaranthaceae) in GbadoLite City, Nord-Ubangi "mentions :

In tropical conditions where soil fertility is fleeting, vegetable yields are less appreciated. This is why most researchers use chemical or organic fertilization to solve this problem. However, the nature of raw materials used to make composts to fine soil and fertilize crops is a limiting factor, especially since these crops are sensitive to the quality of the composts. Moreover, the organic farming system constitutes the best alternative to the use of fertilizers at the Amaranthaceae family level. (Koto-te-Nyiwa Ngbolua et al. 53) 


\subsection{Evaluation of Activities and Estimation of Positive and Negative Impacts}

The main activities involved in this project are as follows:

1. Constructional Activities:

Excavation, digging, eruption, water diversion, mobilization, camping of workers, transportation, piping, access road construction, etc...

2. Operational Activities:

Watering, maintenance, working crew, waste disposal, water distribution, water treatment, etc...

\subsection{Problems \& Obstacles}

In this study, the WHO guidelines were used to identify hazards and risk assessment of the Qom water supply system. For this reason, experts from the water and wastewater company of Qom who had enough information about the WSP program and the risks present in different stages of the water supply system were used. After identifying the hazards by the help of WSP team and also field visits of different sections of the Qom water supply system, Semi-quantitative risk matrix approach was used for ranking the hazards.

The project delays have been caused partly due to certain limitation related to practical execution of the works. This includes limitations and difficulties of the site, such as adjoining and interference of the project route with the over ground as well as the underground utilities, which requires obtaining work permissions from different relevant institutions and city authorities. Avoiding such interferences to prevent possible damages to the existing utilities in the project route requires exactness in positioning. And in certain instances re-positioning the excavation routes, which in turn lowers the pace of execution activities. (Monis P 67)

\subsection{Supply of Material and Construction of Pipeline from Kouchary Dam to Reservoirs}

This project which is a great achievement with respect to improvement of the quality of drinking water in the city of Qom. Even though this project is currently operational, however, due to the need for completion of certain remaining minor works and deficiencies. Mainly finishing of the services roads and completion of the green yards surrounding the 7 reservoirs along the $180 \mathrm{~km}$ pipeline. The water transmission pipeline from the Kouchery Dam to the city of Qom with a total length of $180 \mathrm{~km}$ consists of 2 parts with pipe sizes ranging from $1200 \mathrm{~mm}$ to $2000 \mathrm{~mm}$. The length of the first part which transfers water from Kouchery Dam to the Qom Water Treatment Plant is $108 \mathrm{~km}$ and there are 4 concrete reservoirs along the route of this section of the pipeline, each with a capacity of 15000 cubic meters. This section of the pipeline also includes construction of a chlorination unit, access roads as well as two connections to transfer water to the cities of Mahalat, Khomein \& Golpayegan. The second part of the project consists of a transmission line with a length of 72 $\mathrm{km}$ for transfer of water from the Qom Water Treatment Plant to the Salarieh and Dubaradaran reservoirs in Qom. This part of the project also include three water reservoirs each with the capacity of 10000 cubic meters, access roads and 4 water connection lines for transfer of water to Neizar, Emamzadeh Abdolah and Pardisan, each with specified capacities. 


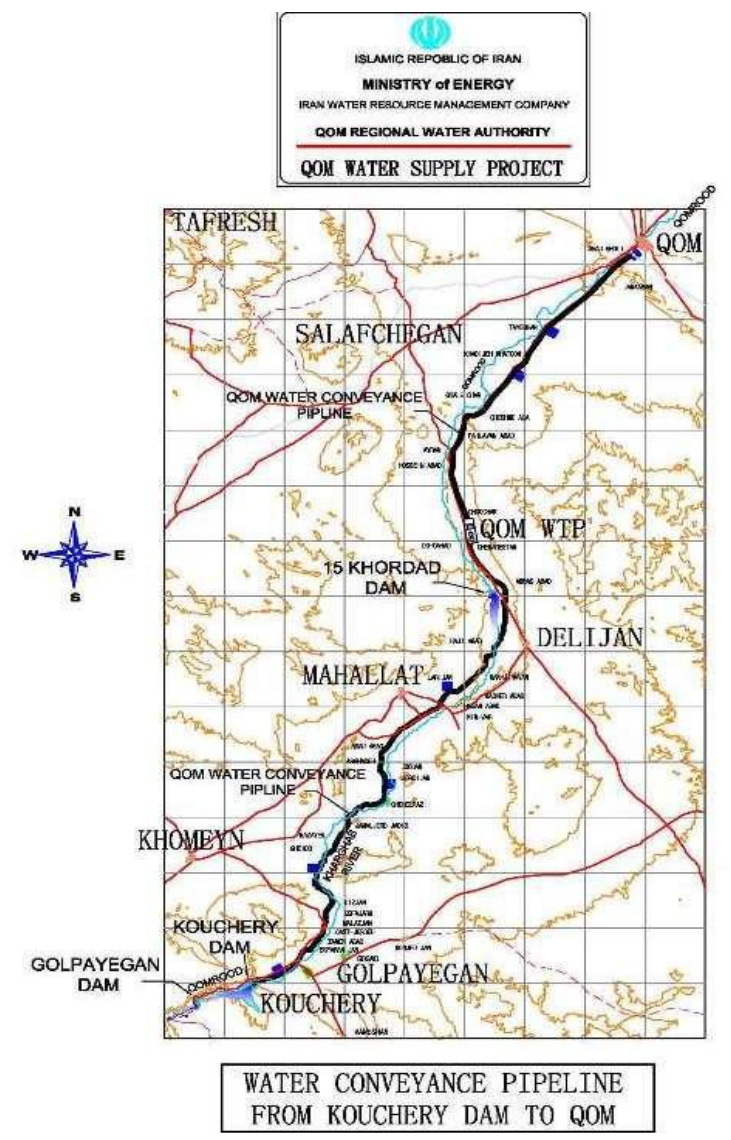

Figure 1. Picture of Qom Water Treatment Plant (1)

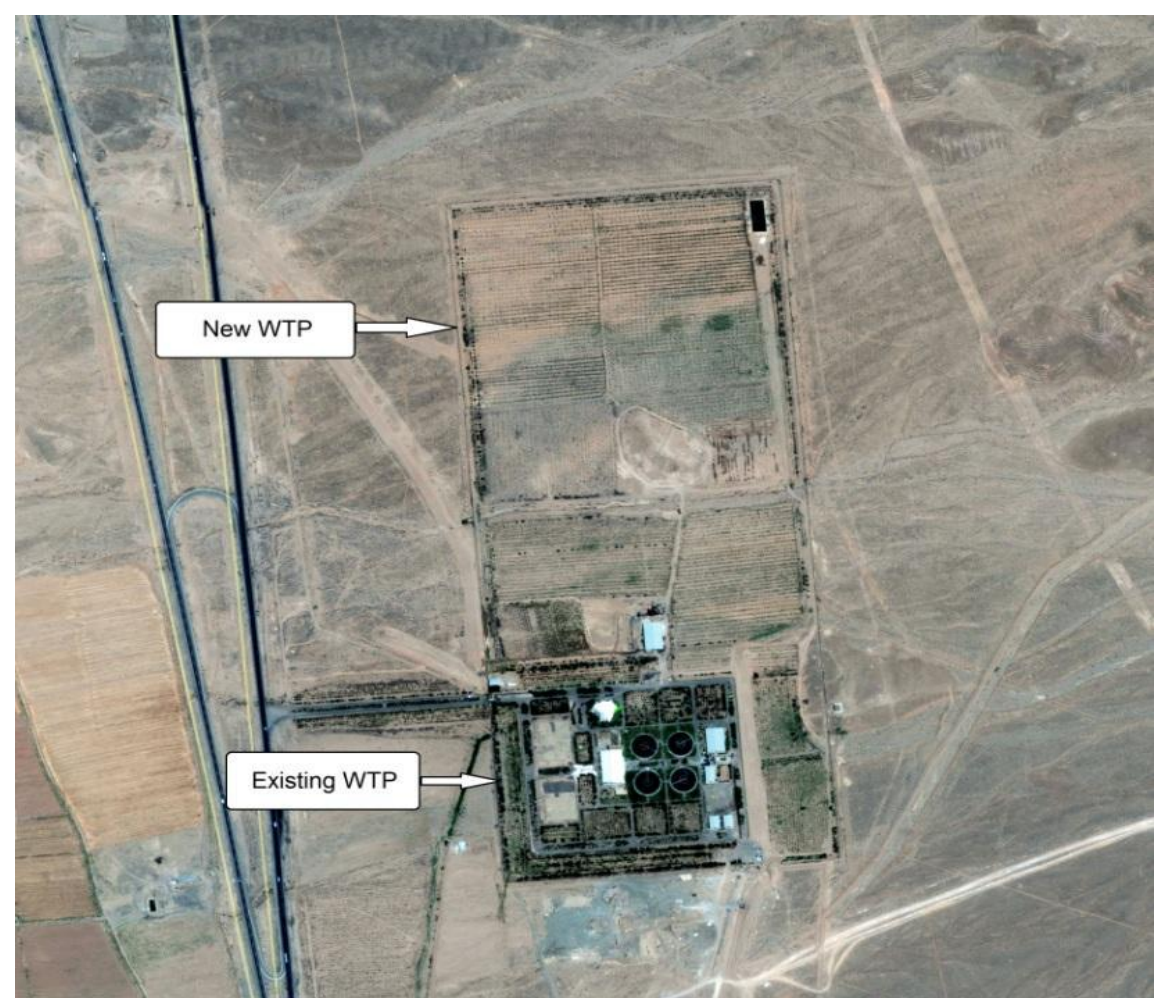

Figure 2. Picture of Qom Water Treatment Plant (2) 
The 2 additional modules of Qom Water Treatment Plant shall be constructed adjacent to the existing WTP in Do-dahak, $20 \mathrm{~km}$ from the city of Delijan. The existing capacity of Qom WTP is 55 million $\mathrm{m}^{3}$ per year, which due to increase of the population in Qom should be expanded. For this purpose, with construction of the new modules an additional capacity of 142.5 million $\mathrm{m}^{3}$ per year would increase the total treatment capacity of Qom WTP to approximately 200 million $\mathrm{m}^{3}$ per year or 6660 liter/second. Connecting the new W'TP to the old treatment plant and also all required pipings and connections are part of contractor's works for this project.

\section{Conclusion}

The risk assessment of the water supply system in Qom showed that there are very serious risks in this system that could endanger the health of citizens if control strategies are not provided. All parts of the Qom Water Supply Project were recognized as the most important criteria for controlling water crisis in Qom and they were subjects of monitoring. In order to increase the quality, the Water Safety Plan should be fully conducted and to control recognition risks, a developed program with enough budgets should be considered. Monitoring of water supply components, especially water treatment should be performed by the organization's specialists and the results should be presented to managers monthly.

\section{References}

Ahmadlia,Z. Fahiminiab, M. (2016) Performance Evaluation of Qom Water Treatment of Plant during 2005 to 2014, Iran. Arch Hyg Sci: 58-65.

Adinew, Melaku, Gebresilasie.G (2019) . Effect of Climate Change on Agricultural Output Growth inEthiopia: Co-Integration and Vector Error Correction Model Analysis. Budapest International Research in Exact Sciences (BirEx) Journal Volume 1.

Monis P, Lau M, Harris M, Cook D, Drikas M. (2017). Risk-based management of drinking water safety in Australia: Implementation of health based targets to determine water treatment requirements and identification of pathogen surrogates for validation of conventional filtration. Food Waterborne Parasitol.

Ngbolua . N, Innocent1.N , Médard.M. (2019). Effect of Agricultural Residues BasedCompost on the Yield of Amarantus hybridus L. (Amaranthaceae) in Gbado-Lite City, Nord-Ubangi. Budapest International Research in Exact Sciences (BirEx) Journal Volume 1, No 4, October Page: 53-61.

Omar Y, Parker A, Smith J, Pollard S. (2017). Risk management for drinking water safety in low and middle income countries - cultural influences on water safety plan (WSP) implementation in urban water utilities. Sci Total Environ : 5(576):895-906.

Rickert B, Schmoll O, Rinehold A, Bahrenberg (2014). E. Water safety plan: a field guide to improving drinking-water safety in small communities. Copenhagen: WHO, Regional Office for Europe.

Rondi L, Sorlini S, Collivignarelli . (2017). MC. Sustainability of Water Safety Plans Developed in Sub-Saharan Africa. Sustainability: 11139-11159.

World Health Organization. (2016). Protecting surface water for health. Identifying, assessing and managing drinking-water quality risks in surface water.http://www.who.int/iris/handle/10665/246196

World Health Organization. (2017). Potable reuse: guidance for producing safe drinkingwater. http://apps.who.int/iris/bitstream/handle/10665/2

Yekta TS, Khazaei M, Nabizadeh R, Mahvi AH, Nasseri S, Yari AR. (2015). Hierarchical distance-based fuzzy approach to evaluate urban water supply systems in a semi-arid region. J Environ Health Science Eng ;13(1):53-65. 